\title{
Regional Development and Cluster Management: lessons from South Africa
}

\author{
Mike Morris \\ School of Economics (Saldru), University of Cape Town \\ mmorris@commerce.uct.ac.za \\ and \\ Justin Barnes \\ School of Economics (Saldru), University of Cape Town
}

April 2006

(Our thanks to Raphie Kaplinsky for helpful comments) 


\section{Introduction}

Regional and local development cannot be separated from globalisation. For the defining characteristic of this era of globalisation (differentiating it from earlier periods of internationalisation) is the international dispersal of the production of manufactured components, globally coordinated, and oriented towards supplying industrialised country markets (Dicken 1998, Kaplinsky 2005). Most enterprises in developing countries do not engage in spot market, arms length trade with their export customers - i.e. thin, transient, relationships. They are instead locked into various hierarchical outsourcing arrangements i.e. 'thick' relationships where lead firms determine production parameters, specifications, and design over the outsourced enterprises (Gereffi et al 2004; Kaplinsky 2005). Consequently issues of operational performance, competitiveness, learning, upgrading or innovation at a regional level are interlinked with global value chain determinants (Humphrey \& Schmitz 2002). Furthermore collective efficiency (i.e. clustering and learning through networking) has played a crucial role in local firms enhancing their productivity, rate of innovation and competitive performance (Bell \& Albu 1999; Maskell et al 1998; Bessant et al 2003; Lawson \& Lorenz 1999; Morosini 2004, Nadvi \& Schmitz 1999, Schmitz 1999a, 1999b, 2004).

On a policy level this is reflected in the importance of developed country government's promoting existing regional clusters (Peck and McGuinness, 2003). However the same cannot be said about developing countries attempting to create clusters and learning networks, for the Washington Consensus has marginalized industrial policy in developing countries (World Bank, 1997). Even though the World Bank has recently come to accept that governments can act as a 'facilitator of networking, as a catalyst of dynamic comparative advantage and as an institution builder, creating an efficient incentive structure to remove systemic and market inefficiencies in (national) systems of innovation'. However 'the creation of clusters should not be a government-driven effort but should be the result of market-induced and market-led initiatives' (www.worldbank.org/urban/led/cluster2.html). According to the Bank, developing countries must strategically shift from policies of direct interventions to ones of indirect inducement - e.g. creating supporting network, dialogue and knowledge exchange structures and schemes. Government should not subsidise firms or sectors in setting up clusters, nor should cluster policy be about limiting market rivalry. Furthermore government should not create clusters from 'scratch' in declining markets or industries. It also should not try to take the direct lead or ownership in cluster initiatives. Instead government should work as a catalyst, a broker bringing actors together, creating forums for dialogues, supplying supporting structures and incentives to facilitate the clustering and innovation process. In short, 'supporting existing and emerging clusters rather than trying to create them from scratch' (Enright and Ffowcs-Williams 2000: 4)

In contrast exponents of industrial policy are relatively silent on governmental purposive action to create clusters. Chang, although a major advocate of industrial policy basically ignores clusters in his published work (Chang, 1994, 1998, 2002). The development literature has cluster advocates and descriptions of the operations of existing clusters (Altenburg and Meyer-Stamer 1999; Humphrey and Schmitz 1995, 1996; Lall 2004; Helmsing 2001, Morosoni 2004) which contains useful policy advice but there is not a huge amount on how to create, sustain, and manage them in a regional framework. ${ }^{1}$ UNIDO's website

\footnotetext{
${ }^{1}$ Altenburg and Meyer-Stamer (1999) identify five areas in which government can help clusters, Humphrey and Schmitz advocate their Triple - $\mathrm{C}$ approach, but as they say, what government should do about it is less clear. Lall (2004) argues cluster facilitation as a part of industrial policy, but doesn't go much further than stressing the
} 
(www.unido.org/clusters) goes the furthest, containing a policy framework for supporting and facilitating cluster development in developing countries. The importance of neutral external intermediaries and brokers in building cluster cooperation is a strong thrust of the policy recommendations. However much of the UNIDO literature is silent on allocating specific responsibilities to external public sector role players (such as government, donors, business associations, international agencies, etc.) and especially on the specific role that developing country governments can or should play in the process.

So, from the perspective of regional development, conventional economic orthodoxy warns against an active government policy, and is very chary of allocating substantial resources to create clusters and networks from scratch. Whilst those who differ with this orthodoxy tend not to be very specific about the manner in which purposive action to create clusters fits in as an integral part of industrial and regional policy. If we are therefore to understand purposive action and agency from a policy perspective we need to tease apart the concept.

Firstly there are two distinct aspects to purposive action to facilitate clustering and networking. The public sphere concerns government policies and implementation activities, whilst the private sphere revolves around external intermediaries (business development services, cluster and network facilitators, consulting firms). The issue therefore is: how to allocate different roles to each? Is government merely a facilitator, a funding agency, and how should the private sector play a leading role?

Secondly, should one eschew starting clusters from scratch, or only work with existing clusters/networks? The answer may be best gleaned from empirical case studies. If this has been done in a developing country, as we argue is the case in South Africa, then it certainly opens up a much wider scope for policy initiatives.

Thirdly, in the process of creating clusters/networks, is it best to do so from above or below? Do we have case study experiences of creating clusters and learning networks which can help to pose appropriate questions and inform us of relevant answers regarding the dynamics of the process of cluster/network creation and development?

Fourthly, which level of governance (central or local) is best positioned to formulate and implement cluster industrial policy? There is often, in our experience a huge gap between the policy supportive framework articulated and the institutional arrangements the state puts in place to implement them. How can we ensure that state support policy for clusters and networks is implemented in a way that facilitates policy objectives rather than obstructs them?

Fifthly, is policy different in creating clusters or learning networks? That is, collective action sharing activities/costs to create collectivised scale economies, or cooperative activities to facilitate learning and raise operational competitiveness within each enterprise.

In order to unpack these questions we examine clusters and learning network experience in the automotive, clothing and textile sectors in South Africa.

role of clusters in building absorptive capacity in firms and government. Helmsing (2001) makes a case for significant public policy adjustments and stresses the importance of the state's role in the process, particularly in its regional and local form. Morosoni (2004) posits a range of roles that public policy makers, through government interventions, can play in fostering the development of clusters and associated learning activities. 


\section{The Automotive Component Benchmarking Clubs}

In the mid-1990s South Africa shifted from import substituting industrialization to trade liberalisation, a major drop in tariff protection and rapid integration into the world economy. This posed major challenges for the automotive component sector which was faced with the need to rapidly become internationally competitive. With government support measures providing 65\% funding a learning network was established in 1998 called the 'KwaZuluNatal Benchmarking Club’ (KZNBC) comprising 11 component makers and one assembler, facilitated by a private service provider ${ }^{2}$, and operating as a manufacturing excellence learning network (Barnes \& Morris 1999). Central to this was the use of a benchmarking model of key competitiveness drivers (see table 1).

Table 1: The Critical Success Factor/Market Driver Matrix measuring operational performance

\begin{tabular}{|c|c|c|}
\hline Market drivers & Operational performance measures & Linked organizational practices \\
\hline Cost control & $\begin{array}{l}\text { Inventory use (raw materials, work in } \\
\text { progress, finished goods) }\end{array}$ & $\begin{array}{l}\text { Single unit flow, quality at source, } \\
\text { cellular production, kanbans }\end{array}$ \\
\hline Quality & $\begin{array}{l}\text { Customer return rates, internal reject, rework } \\
\text { and scrap rates, return rates to suppliers }\end{array}$ & $\begin{array}{l}\text { Quality control structures, statistical } \\
\text { process control, quality circles, team } \\
\text { working, multi-skilling }\end{array}$ \\
\hline $\begin{array}{l}\text { Lead times } \\
\text { (Value chain flexibility) }\end{array}$ & $\begin{array}{l}\text { Time from customer order to delivery, } \\
\text { delivery frequency of suppliers and supplier } \\
\text { delivery reliability, delivery frequency to } \\
\text { customers and delivery reliability }\end{array}$ & $\begin{array}{l}\text { Business process engineering, } \\
\text { cellular structures, processing and } \\
\text { dispatch, value chain relationships } \\
\text { and supply chain management }\end{array}$ \\
\hline $\begin{array}{l}\text { Flexibility } \\
\text { (operations) }\end{array}$ & $\begin{array}{l}\text { Manufacturing throughput time, machine } \\
\text { changeover times, batch sizes, inventory } \\
\text { levels, production flow }\end{array}$ & $\begin{array}{l}\text { Production scheduling, JIT, single } \\
\text { minute exchange of dies, multi } \\
\text { tasking and multi-skilling, cellular } \\
\text { production in manufacturing }\end{array}$ \\
\hline $\begin{array}{c}\text { Capacity to } \\
\text { change } \\
\text { (Human Resources) }\end{array}$ & $\begin{array}{l}\text { Literacy/numeracy, suggestion schemes, } \\
\text { employee development/training, absenteeism } \\
\text { rates, labour/management turnover, } \\
\text { employee output }\end{array}$ & $\begin{array}{l}\text { Continuous improvement (kaizen), } \\
\text { work organisation, worker } \\
\text { development and commitment } \\
\text { programmes, industrial relations }\end{array}$ \\
\hline $\begin{array}{l}\text { Innovation } \\
\text { capacity }\end{array}$ & $\begin{array}{l}\text { R\&D expenditure (process and product), } \\
\text { Contribution of new products to total sales }\end{array}$ & Concurrent engineering, R\&D \\
\hline
\end{tabular}

The executive consisted of firm representatives controlling policy, budget and payments, with two facilitators as non-voting members. The following services were provided to members:

- A confidential diagnostic report of each firm providing confidential, evidence-based feedback on performance. The report measured operational performance, the major customers assessment of its performance, the firms perception of its major suppliers performance, as well a benchmark against a 'like for like' international competitor.

- A monthly newsletter outlining aggregate benchmark data for the whole network.

- Quarterly 'best practice' inter-firm workshops discussing generic findings, common problems and emerging solutions.

- Encouraging information sharing between firms through inter-plant visits, etc.

The first difficulty encountered was a lack of trust, an unwillingness to share information and a tendency to blame others for emerging problems - government, suppliers, customers. This changed as members took ownership of the network, and workshops were run in the factories themselves, signalling a shift towards more open experience-sharing and trust-building.

\footnotetext{
${ }^{2}$ The private sector facilitation services arose from research by Justin Barnes and Mike Morris, since these were not academic activities. Justin Barnes is the fulltime CEO of Benchmarking and Manufacturing Analysts (BMA - www.bmanalysts.com). He is also a research affiliate of SALDRU, University of Cape Town..
} 
The Club's success led to four similar networks being established in other industry centres Port Elizabeth, Gauteng, East London, and Cape Town. In total 70 firms belong to these networks, linked by a common service provider and sharing generic resources. Although each have differing agendas depending on the local assemblers, there is considerable interchange with inter-firm visiting and participation in workshops between regions. Consequently knowledge sharing has developed into a national capability across the sector.

The risk with concepts like 'learning networks' is that they become synonymous with general meetings and gatherings which would happen anyway arising from day-to-day sectoral operations. We suggest it is possible using these key indicators to measure the concept and assess network effectiveness in supporting learning and knowledge development:

- increasing knowledge sharing, - e.g. willingness to present to other member firms on achieving significant success on some of the key performance indicators

- significant knowledge transfer - e.g. recorded spontaneous firm visits between members, involvement in joint projects with confidential information sharing;

- major improvement in operational performance - e.g. reflected in the competitiveness indicators measured annually;

- spread of the Clubs as new members were attracted.

However the two most significant criteria of success are network sustainability, and demonstrable internalization of firm level learning. The former is clearly apparent by the decision to become completely self reliant in January 2004, after national government reneged on the promise of three year funding and the Clubs were faced with dissolution. The various club executives decided to ensure long term sustainability by creating a national South African Auto Benchmarking Club with branch chapters solely dependent on private firm subscription fees.

Considerable qualitative data exists to measure knowledge sharing and information transfer. There is clear evidence of growth in the network's popularity through membership expansion - firms clearly perceived the activities as beneficial. But the most significant indicator of learning success is actual improvements in operational performance which member firms attributed to their participation in the network. The Clubs are primarily based on firms wanting to ensure continuous improvement and operational performance enhancement in order to make them more internationally competitive. The driving force underlying knowledge sharing and upgrading is benchmarking the operational performance of member firms against other club members as well as against international comparators. Therefore the best quantitative indicator is the improvement in the operational performance of firms. In conjunction with internationally comparative data it is possible to see the nature and rate of performance improvement. Table 2 presents this in summary and aggregated format ${ }^{3}$.

\footnotetext{
${ }^{3}$ Presenting time series data to compare performance is difficult where membership is constantly growing. One cannot compare performance averages based on 56 firms in 2004 with 25 firms in 1998. Hence the data is presented separately for two samples and sets of years - the original sample (1998/9 - 2001) and a sample of firms joining in 2001 tracked to 2004. The discrepancy in 'lead times' results from the way data is collected. International firms performance is static as no consistent time series data is available.
} 
Table 2: Operational performance change - Club firms (1998/9-2001) and (2001- 2004)

\begin{tabular}{|c|c|c|c|c|c|c|c|c|c|c|c|c|c|}
\hline \multirow{2}{*}{\multicolumn{2}{|c|}{$\begin{array}{c}\text { Market Drivers } \\
\text { Key Performance Indicators }\end{array}$}} & \multicolumn{8}{|c|}{ South African Firms } & \multicolumn{4}{|c|}{ Comparator Firms } \\
\hline & & $\mathrm{n}$ & \multirow{2}{*}{\begin{tabular}{|r|}
$\mathbf{1 9 9 8} / \mathbf{9}$ \\
32.33 \\
\end{tabular}} & \multirow{2}{*}{$\begin{array}{l}2001 \\
21.77\end{array}$} & \multirow{2}{*}{\begin{tabular}{|l|} 
Change \\
$32.7 \%$ \\
\end{tabular}} & \multirow[b]{2}{*}{55} & \multirow{2}{*}{$\begin{array}{c}2001 \\
23.26\end{array}$} & \multirow{2}{*}{$\begin{array}{l}2004 \\
20.50\end{array}$} & \multirow{2}{*}{\begin{tabular}{|c}
$\begin{array}{c}\text { Chang } \\
\boldsymbol{e}\end{array}$ \\
$11.9 \%$
\end{tabular}} & \multicolumn{2}{|c|}{$\mid \begin{array}{l}\text { Developed } \\
\text { Economies } \\
\mathrm{n}\end{array}$} & \multicolumn{2}{|c|}{$\begin{array}{l}\text { Emerging } \\
\text { Economies } \\
\mathrm{n}\end{array}$} \\
\hline \multirow{4}{*}{$\begin{array}{c}\text { Cost } \\
\text { control }\end{array}$} & Raw material (Days) & 24 & & & & & & & & 12 & 11.42 & 43 & 18.83 \\
\hline & Work in progress (Days) & 24 & 12.40 & 8.15 & $34.3 \%$ & 55 & 7.10 & 6.92 & $2.6 \%$ & 12 & 6.40 & 43 & 7.18 \\
\hline & Finished Goods & 24 & 17.82 & 12.12 & $32.0 \%$ & 55 & 12.25 & 10.41 & $15.0 \%$ & 12 & 8.17 & 43 & 9.33 \\
\hline & Total inventory (days) & 24 & 62.56 & 42.03 & $32.8 \%$ & 55 & 42.61 & 37.83 & $11.2 \%$ & 12 & 26.03 & 43 & 35.90 \\
\hline \multirow{5}{*}{ Quality } & Customer return rate (ppm) & 23 & 3270 & 1240 & $62.0 \%$ & 43 & 1,558 & 276 & $82.3 \%$ & 11 & 266 & 34 & 1,127 \\
\hline & Internal reject rate (\%) & 25 & 4.90 & 3.89 & $20.7 \%$ & 38 & 3.87 & 3.26 & $15.8 \%$ & 12 & 1.44 & 47 & 1.73 \\
\hline & Internal rework rate (\%) & 19 & 3.14 & 2.40 & $23.5 \%$ & 39 & 2.76 & 2.79 & $\begin{array}{r}- \\
1.05 \% \\
\end{array}$ & 11 & 2.14 & 34 & 1.90 \\
\hline & Internal scrap rate (\%) & 24 & 4.24 & 3.51 & $17.2 \%$ & 41 & 1.98 & 1.74 & $12.1 \%$ & 8 & 0.32 & 14 & 1.51 \\
\hline & Supplier return rate (ppm) & 21 & 21989 & 18518 & $16.0 \%$ & 41 & 16,330 & 11,645 & $28.7 \%$ & 8 & 7,470 & 34 & 9,506 \\
\hline \multirow{5}{*}{ Flexibility } & Lead time (days) & 19 & 19.9 & 17.9 & $9.9 \%$ & & & & & & & & \\
\hline & $\begin{array}{l}\text { Lead time ex prod } \\
\text { (domestic - days) }\end{array}$ & & & & & 50 & 8.50 & 7.69 & $9.6 \%$ & 7 & 7.57 & 18 & 4.57 \\
\hline & $\begin{array}{l}\text { Lead time ex prod } \\
\text { (global - days) }\end{array}$ & & & & & 29 & 43.63 & 43.54 & $0.2 \%$ & 6 & 7.83 & 8 & 27.94 \\
\hline & Supplier on time (\%) & 23 & 78.7 & 82.2 & $4.5 \%$ & 50 & 86.25 & 88.41 & $2.5 \%$ & 13 & 93.88 & 47 & 89.19 \\
\hline & On time to customers (\%) & 25 & 92.2 & 92.7 & $0.6 \%$ & 53 & 91.25 & 93.21 & $2.1 \%$ & 14 & 97.66 & 48 & 93.69 \\
\hline \multirow[t]{2}{*}{$\begin{array}{l}\text { Capacity to } \\
\text { change }\end{array}$} & $\begin{array}{c}\text { Training spend as \% total } \\
\text { remuneration }\end{array}$ & 30 & 1.3 & 2.0 & $56.2 \%$ & 53 & 2.06 & 1.95 & $-5.3 \%$ & 11 & 2.05 & 34 & 4.39 \\
\hline & Absenteeism (\%) & 27 & 4.4 & 4.0 & $9.4 \%$ & 57 & 4.14 & 3.57 & $13.8 \%$ & 12 & 4.01 & 47 & 5.40 \\
\hline $\begin{array}{c}\text { Innovation } \\
\text { capacity }\end{array}$ & R\&D expenditure (\%) & 24 & 1.64 & 2.12 & $29.5 \%$ & 33 & 0.95 & 1.01 & $5.5 \%$ & 12 & 1.96 & 17 & 2.42 \\
\hline
\end{tabular}

The learning impact on operational performance has been significant even if the South African components sector has some way to go to reach the global frontier. With the exception of delivery reliability to customers, progress for all of the measures in South Africa has been significant. Generally speaking, domestic performance is better where internal factors (work-in-progress control, training, absenteeism) are involved than where they are dependent on external factors (raw material inventories, supplier performance). From a value chain perspective this suggests that the growth of learning is still predominantly in the firsttier components suppliers and has not yet diffused sufficiently up the chain. Some of inventory control weakness is due to value chain logistic problems, especially with regard to incoming materials (minimum-sized import quantities; problems at the ports) and distance to the export market (for stocks of finished goods). In general there are clear indications that significant process upgrading has occurred and the firms are becoming more internationally competitive. Clearly external factors have also contributed, but the members argue that the cooperation, knowledge sharing and learning embedded in the operations of the clubs have played a major and critical role in the process (Barnes \& Lorentzen 2004).

There is still some distance from the international frontier but these firms are clearly learning rapidly. A number of other factors have also contributed but the qualitative data mentioned earlier suggests that firms perceive considerable value in shared learning as a way to accelerate learning progress. The limits to horizontal co-operation can be seen in the relative lack of impact on inter-firm issues, suggesting that some form of vertical co-operation is also needed to help with sector development (Bessant et al. 2003). 
How do we assess government institutional levers in this process? Without the existence of a auto sector specific industrial policy coupled with cross-sectoral policy levers which allowed the service providers to access financial support for clustering (Barnes etc al 2004), the Benchmarking Clubs would never have emerged and been sustainable in their early years. Yet one of the most striking difficulties experienced by the Clubs was the institutional difficulties associated with the support received from the national government. Government abandoned import substituting industrialisation, adopted new policies and the Department of Trade and Industry (DTI) had employed new personnel. But the administrative structure remained intact and there was insufficient re-conceptualisation of the deployment implications of these policies and hence reconfiguring of the institutional arrangements to ensure that implementation followed the policy shift. The support measures were immersed in bureaucratic red tape and it was extremely difficult to access them. The long lead times associated with the department's previous practice - lobbying for tariff protection or requesting various licensing permits - were no longer adequate in this new era of international competitiveness. Furthermore the knowledge implications of the policy shift required retraining staff, shifting their centre of gravity as "paper pushers" to agents of change fully attuned to the competitiveness demands being placed on South African firms.

Whilst it was easy obtaining formal government support, practically establishing the Club was more difficult. The launch was seven months late and then took a further five months for the first government payment. Moreover, as time progressed, the Clubs (and service providers incurring the actual costs) discovered that providing a 65\% subsidy proved a double edged sword. For the DTI invariably took between 3-6 months to respond to invoices, and consequently the service providers facilitating Club activities constantly experienced cash flow crises. Lengthy procedures created considerable uncertainty, payment delays threatened to derail activities - all resulting in loss of participant confidence. Furthermore, since the service provider had to pay VAT on invoice and not on receipt of government payment, this placed further pressures on the viability of the networks, incurring excessive administrative time in generating resource certainty. Ironically, the DTI reneging on its promise of block funding unintentionally forced the Clubs to confront the issue of long term sustainability. They became completely self financing, dependant only on membership fees, finally solving the continuous recurring cash flow crises engendered from erratic government support.

In short, there was a lack of alignment between national government policy goals, strategies and these networking activities taking place outside its immediate ambit. Secondly, the inability of central government to put in place the appropriate institutional arrangements to create an enabling environment also nearly killed the initiative, but inadvertently created the conditions for the learning network to move onto another level.

\section{The Durban Auto Cluster}

The initial stimulus for setting up the Durban Auto Cluster (DAC) came from the municipality who were keen to foster regional development. Toyota SA, the major assembler in Durban, had secured a significant export order and the opportunity presented itself to work with them and key suppliers to enable regional economic growth.

The existing infrastructure and high trust within the KZN Benchmarking Club was used to initiate the DAC. In June 2001 the external facilitators proceeded in the following manner:

- firms in the local value chain (40 in total) were identified, visited, and invited to participate, without financial obligation, 
- workshops involving the major actors were held;

- international research on cluster success was disseminated,

- local, provincial and central government support provided political legitimacy;

- a needs survey was undertaken on key issues affecting the local industry;

- participants voted to identify four focus areas - logistics, human resources, supply chain, and operational competitiveness;

- technical task teams comprising firm representatives managed these focus areas, identified key issues, wrote a one year business plan with program goals, activities, and designated budgets;

- a final workshop discussed these plans, a (firm-based) governance structure, a budget, government support, membership fees, etc and firms voted to launch the cluster, signing up as members.

The DAC as a public-private initiative was formally launched in Jan 2002. ${ }^{4}$ Most of the finance came from local government with firms also paying membership fees. The four development programmes ${ }^{5}$ were run by technical steering committees controlling programme activities and expenditure, chaired by firm representatives, with technical support from the service provider. The executive comprised the technical task team chairs, government representatives, and facilitators.

Operationally the DAC operates in the following manner:

- providing key operational services,

- enabling financial saving through joint activities,

- knowledge sharing through workshops and a newsletter,

- joint research,

- access to an on line data base.

The four core programmes operate in the following manner:

1. The logistics programme shares information, creates price transparency, secures fair pricing and reduces costs through consolidation and load balancing across sea, road and air. Logistics accounts for between $5-15 \%$ of selling costs, hence critically affecting competitiveness. A logistics costs survey showed that sea freight charges for smaller firms were double those of the larger firms, affecting competitiveness throughout the value chain. Hence the drive to cut freight costs. Freight rates were 'benchmarked' and linked to average prices for member firms. A special 'cluster rate' was negotiated between Europe-SA for all cluster participants ${ }^{6}-\$ 1300$ per $20 \mathrm{ft}$ container compared to $\$ 2500$ smaller firms paid.

2. Supplier Development focuses on raising purchasing skills, aligning purchasing functions, developing a supplier awareness database, and information sharing. Activities include identifying training needs, exchanging knowledge and running purchasing and supply management 'best practice' workshops. Aligning purchasing functions was achieved through a common approach to supplier management by

\footnotetext{
${ }^{4}$ The DAC currently has 42 participating firms paying membership fees, 20 more than when it was launched.

${ }^{5}$ This programme will not be discussed here since it is simply the incorporation and expansion with new members of the KZN Benchmarking Club, which we have already discussed, into the DAC.

${ }^{6}$ At least one of the larger firms with huge volumes pay even less than the negotiated cluster rate.
} 
OEMs and $1^{\text {st }}$ tier suppliers. A comprehensive directory of all suppliers to improve selection and facilitate comparison was created.

(iii) The Human Resource Development programme established a forum to interface with the government training organisation as most firms are unaware of training grants or are unable to follow their complicated administrative procedures. A local training institute has developed a basic adult education programme. Finally to achieve collective scale economies a joint training scheme provided nine technical training courses attended by 200 staff from twenty two firms, the cost saving being about $30 \%$ per delegate (figure 1 ).

Fig 1: Joint training savings for participating firms: 2004

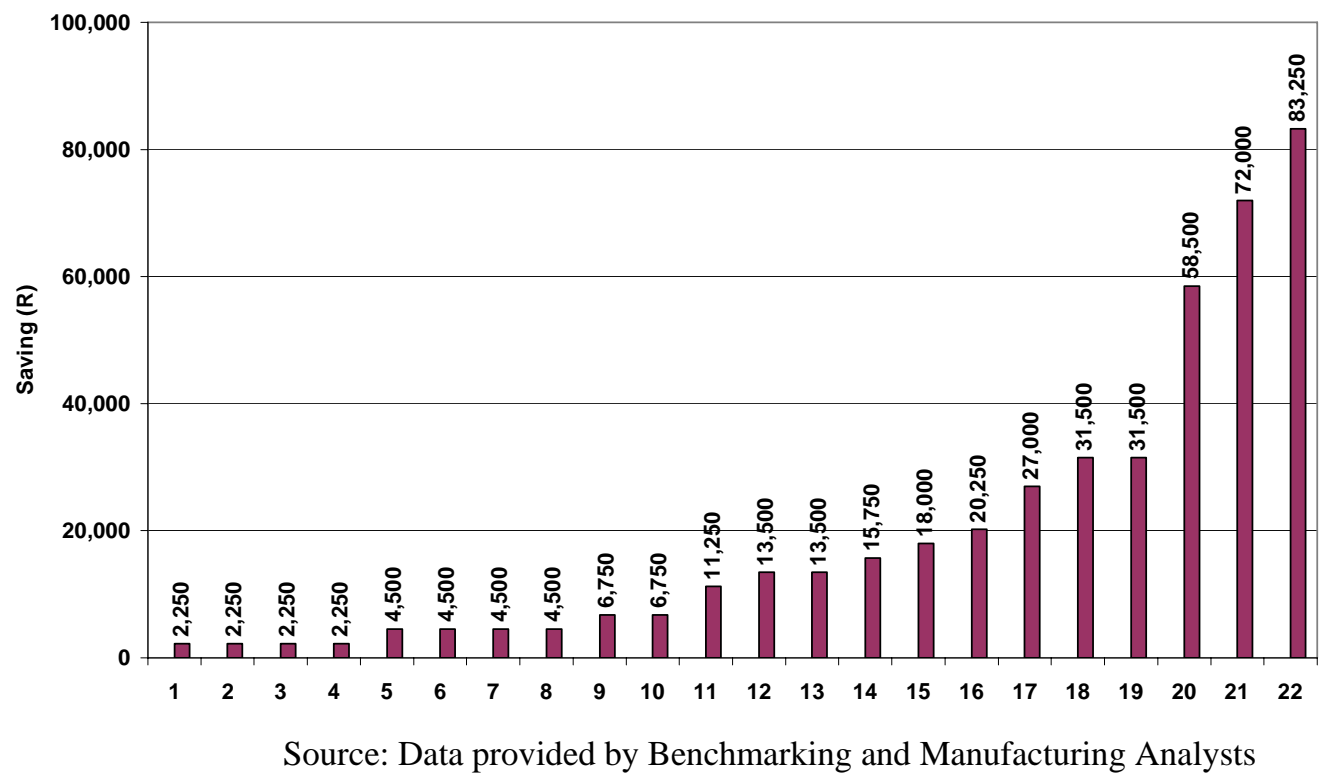

Whilst Toyota's support is important, it was agreed by all that it would take a back seat. This enabled suppliers to feel comfortable working on strategies without feeling dominated by the powerful assemblers.

The DTI offers inconsistent support and erratic interest - national representatives rarely participate in the local activities, and no funding was provided. Responses to funding applications have been inadequate, as departmental bureaucrats have little direct experience of the cluster or its participants. In any case the DTI's funding procedures required meeting criteria too precise to allow for the flexibility necessary in facilitating firm-based clustering. Despite numerous promises, the DAC never received any earmarked funds. Requests for more direct involvement were met with a view that the DTI has to be distanced from regional processes and focus on strategic national activities. This persists despite the DAC being one of the government's most successful cluster projects.

The DAC's relationship with provincial government has also been fraught with inflexibility, beset by delays and uncertainty with respect to funding support. Furthermore provincial department was prone to hijacking the cluster for its own political interests. In return for funding, it was wont to issue policy directives requiring the DAC to focus on matters which were not its core businesses. 
The relationship with the local metro level government is markedly different. The metro government, concerned with Durban's problems in regenerating its industrial base, was acutely aware of the local automotive industry's importance. It was also aware, as a result of numerous interactions, of the success of the KZN Benchmarking Club. This institutional intimacy enabled it to play a proactive role. The Metro government has become the primary source of public funding for the DAC, and the incessant cash flow problems experienced through accessing national government funds has ceased. The Metro is embedded in the DAC, and this is apparent from the continuous presence of its representatives at the quarterly workshops, as well as the numerous occasions the Deputy Mayor and Metro CEO have been guest speakers. The facilitators meet regularly with local officials to discuss a variety of relevant issues, and an informal monitoring process is embedded in this working relationship

\section{Cape Clothing and Textile Cluster and KwaZulu-Natal Clothing and Textile Cluster}

The clothing and textile industries were taking severe strain as a result of changing global circumstances (Kaplinsky 2005). The entry of China into the WTO and the end of the quota based Multi-Fibre Agreement resulted in Chinese imports flooding into the domestic market. Furthermore the rapid appreciation of the Rand over the last few years (coinciding with China's entry into the WTO) resulted in clothing exporters international inefficiency being rapidly exposed and a substantial fall in exports. In short clothing and textiles was bleeding jobs and enterprises (Morris et al 2006,). Since these two domestic sectors were concentrated in the Western Cape and KwaZulu-Natal, there was major pressure on the respective provincial governments to assist the industry. Knowing of the successes in the auto sector, these provincial governments separately approached the facilitators (BMA) to initiate clothing clusters, providing start-up funding. These two clusters were respectively initiated in late 2004 and early 2005 and followed a similar model as the DAC.

The set up process took the following familiar form:

- Define, review, create consensus through firm level benchmarks and interviews to tease out the opportunities, constraints, obstacles and competitiveness issues.

- Entrench support for clustering via firm-level and regionally based workshops

- Produce background analysis of the provincial clothing and textiles sectors trends and secure agreement on major problem areas

- Develop industry led strategies tackling key issues and areas of intervention

- Transfer institutional ownership to sector champions, through technical steering committees, business plans, budgets and realizable development programs.

- Set up a public private partnership between government and firms, through the facilitation of a neutral service provider.

Both clusters were launched with programmes solely focused on ensuring manufacturing excellence upgrading - collective efficiency, knowledge sharing, and continuous improvement learning activities. ${ }^{7}$ Upgrading operational performance towards world class manufacturing is of particular importance in this sector, for management traditionally has low knowledge levels and lacks appreciation of manufacturing excellence. Firms still tend to externalise problems, and hope that a silver bullet from an outside agency will save them. Hence the stress in these two clusters on making firms focus internally on rapidly improving their operational performance to become more internationally competitive.

\footnotetext{
${ }^{7}$ These two clusters have not been operative long enough to quantitatively assess the impact on the competitiveness of member firms.
} 
The differentiating feature of clothing and textiles is the critical lead role played in the domestic value chain by the large domestic retail firms which hold the future of the firms in their supply chain in their hands. Hence the major strategic initiative has been a) to draw the retailers into supporting local industry upgrading, b) on this basis build a 'Business Alliance' between all links in the value chain, and c) massively accelerate the impact of the clusters by getting the big retailers to join them and encourage their suppliers to do likewise (Business Report 7/4/06). The success of these three initiatives place the CCTC and KZNCTC in a unique position of encompassing the entire value chain within their institutional confines and radically facilitating horizontal and vertical cooperation.

\section{CONCLUSION}

This chapter began paper by raising a number of general issues to be tested on the basis of the South African case study experience. Can clusters and learning networks, using industrial policy and government levers in developing countries, be created from scratch? Is there any proof that this is beneficial to the firms involved? If the answer is in the affirmative, then what analytic (as opposed to highly practical) lessons can be gleaned in respect of creating clusters from below or above? How should we understand the role of government (in its different tiers) and that of cluster facilitators in doing this? Finally, in understanding these processes, can one discern differences with respect to clusters and learning networks?

The first set of questions centred around whether clusters and learning networks can and should be created? The South African experience is yes, under certain circumstances and following certain processes, it is possible to create them where existing industrial capacity exists but cooperation is absent. Furthermore, as the data and descriptions clearly verify, they can lead to extremely beneficial results. The data cited and the examples provided of marshalling scale economies and internalising learning is unequivocally positive. So why do we find resistance in the literature to government providing funding and marshalling human resources to foster clusters? There are a number of sources to such resistance. Some, such as the serious lack of institutional and human resource capacity in many developing country governments are legitimate and have to be taken very seriously. Others arise from a knee jerk, ideological reaction to allocating public resources to pre-selected firms rather than creating policies which are available to all. The rationale behind this is a perfectly laudable concern to husband public resources and cut out rent seekers, to which we turn later on.

This is presumably also the basis for the World Bank's warning that clusters should not be a government-driven, not subsidized by public funds, and that government should not try and create them from 'scratch'. However there is a conceptual problem with this position. For it assumes stasis in the core competency of firms, takes capabilities as given and operates without a concept of building dynamic capability (Teece and Pisano 1994). But then how are firms in developing countries to change their capabilities, upgrade and move onto a new innovation regime without some external facilitating process? Most firms in developing countries externalise their problems. They don't understand the need to upgrade, and even when they do, don't have the internal capacity to change or build on their core competency. This is the important role of government in regional development processes - to push firms out of their current stasis, to break vested interests, and to incentivise firm-level upgrading. As is borne out by the South African case studies, clustering is a way of doing so in a manner that is ultimately risk reducing, because it spreads risks, reduces upgrading costs and collectivises efficiency gains. 
What then about rent seeking? This is entirely dependent on the process and structure adopted. The case studies show how a process can be constructed which cuts out, or at least cuts down, rent seeking. Firstly the public cash contributions involved are relatively small. The South African Benchmarking Club's current annual budget is around \$239,000. The Durban Auto Cluster's annual budget is around \$212,000. The newly created Cape Clothing Cluster budget is around \$196,000, and the recently launched KZN Clothing and Textile Cluster budget is $\$ 290,000$.

Secondly, requiring firm contributions acts as an important check on how programme monies are spent. The South African Auto Benchmarking Club is wholly funded by members, the Durban Auto Cluster depends on between 40-50\% member funding, and both the clothing and textile Clusters depend on 25\% membership contributions. Firms are more careful about spending public money when their own contributions are integrally tied into the budgets.

Thirdly, the institutional relationship between the government, firms, and the facilitators acts as an important control over expenditure. The contributions are paid into a legally constituted institution formally separated from the service provider, which the latter has to invoice for all activities and associated costs. Expenditure occurs through the clusters executive, dependant on the programme business plans managed by each technical steering committee to meet programme objectives and budget targets, thereby providing substantial countervailing checks and balances.

Finally the large contribution in kind from firms (time, energy, knowledge) builds in controls. This not only creates buy-in from the membership, but also ensures responsibility and accountability from firms for operational activities. Indeed some clusters are costing such contributions to offset them against the individual firm's membership payment.

Essentially, this structure has created a situation where it is difficult for cluster participants to dupe government and put money into their own pockets. All expenditure falls within a business plan. One way rent seeking can occur is if firms themselves do not take up participation in the various programs, and then it is the private sector and not the public sector that loses out. Ultimately large scale fraud would require the compliance of all role players for substantial rent seeking to take place.

In thinking through the role of public funding, it is useful to contrast the differences between the clusters and the learning networks. This can be empirically captured through asking a question: what dynamics allowed for full membership payment in the South African Benchmarking Club (learning network) and would this be possible for the auto and clothing/textile clusters? The answer lies in the difference between a learning network designed to upgrade individual firm capabilities and a cluster operating to achieve collective efficiency through cooperative economies of scale. The benchmarking clubs are based on cooperation, but they are all about individual firms cooperating in order to internalise knowledge so as to upgrade. They are essentially built on a spine of enhancing private firmlevel competitiveness. Hence, once the Clubs had proven success, members were susceptible to them becoming wholly self supporting. Indeed it was wholly appropriate, if accidental and potentially disastrous in its timing, for government support to come to an end at some point.

The clusters, on the other hand, are based on achieving externally induced cooperative scale economies through substituting for what could instead have been the provision of public goods. The services the clusters provide all mirror this. For example, data provision and 
knowledge and enhancement is the provision of information, which should be a public good provided by public authorities. Collective training is a public good that should be provided by government sponsored training institutions. Brokering, joint negotiation, joint marketing, etc. are often services subsidised by government trade facilitation bodies. Member firms regard many of the clusters' collective efficiency services as partly public goods and hence it is appropriate for their costs to be shared with public sector. That is also why they don't regard accessing these services through the cluster as rent seeking.

Such issues may bother academics concerned with the theoretical questions of government's role vis a vis the private sector. But for those grappling with implementing regional development policies and using purposive action to create a cluster or learning network, the issues are concrete and institutionally located. As the experience of the South African case studies demonstrates, the big flaw in the relationship between government and clusters is much more mundane - it lies in government's inability to translate policy decisions into the institutional arrangements to ensure that the strategic policy goals can be implemented. Whilst it is indisputable that without public funding these clusters would never have got off the ground, these clusters have succeeded in spite of, rather than because of, the way these resources were institutionally distributed. There are a number of reasons for this implementation failure, as well as policy lessons that flow from them.

Essentially, the South African DTI ignored reconfiguring its institutional arrangements to create a flexible delivery mechanism. Instead it wrapped the process up in bureaucratic time consuming unnecessary activities instead of the first principles of lean manufacturing flexible and quick response times. This was compounded by the DTI's lack of human capacity skills, and the refusal to realise that this was a way for its sector personnel to learn through an iterative relationship with the clusters. Instead it engaged in an endless cycle of high profile and expensive management restructuring exercises. The result was that any specific training invested in the sector directorates was wasted, and the department bled demoralised staff at an alarming rate. Good industrial policy is far more than a process of abstract formulation, it also requires continuously learning, government staff embedded in sector dynamics. Furthermore, the DTI did not build internal institutional arrangements to intersect national industrial policy with locally based cluster initiatives. Hence, the local cluster initiatives were institutionally dislocated (in funding, accountability, and report back relationships) from national government initiatives, dependant on fragile personal relationships.

Correspondingly local government's ability to create the institutional arrangements points to the issue of institutional location. Central government was too far away and distant from the firms to be institutionally embedded in their needs, problems, requirements, and cluster activities. It was unable to monitor and appreciate the cluster and network successes, and track the enterprises movement towards international competitiveness. In short it lacked the institutional intimacy to set up appropriate institutional arrangements of implementation. Delivery agencies do not have to be located at the same government level as resource allocating tiers. In the case of the DAC, central government funds were accessed by the local tier for kickstarting the cluster. Resource allocation was located at central level whilst allowing for its drawdown and implementation to occur at lower government levels. Unfortunately, since it was purely accidental and ad hoc, it also illustrates the weaknesses, and policy irrelevance, of the process.

Most public-private partnerships are viewed as a relationship between two parties government and firms. However it is clear from the above case studies that creating clusters 
and learning networks from below through purposive action requires the application of particular skills on the part of external intermediaries - the facilitators. Indeed there are actually three parties involved, and the problem is that the one that is most crucial from the perspective of agency tends to be left out of the policy equation. The facilitators are private sector, but they distinctively different from the manufacturing enterprises who are the real targets of industrial and cluster policy. The facilitators' task is to assist firms upgrade, cooperate and become more competitive. They are the conduits of policy, creating the link between state and manufacturing, the third arm of this triangle, linking the state's enabling environment and supportive financial structure and the manufacturing enterprises. Hence a key conclusion is the need to close the magic triangle. By posing the question in terms of state versus market - either government drives clustering or it allows the market to lead - this essential element gets lost. Instead the central question is: how does government industrial policy build an effective business services sector to assist enterprises in building this new manufacturing economy? Supporting the private sector and creating public private partnerships requires government to recognise, support and reward the important role of the business services sector in delivering the sorts of direct interventions to raise the competitiveness levels of industry that government requires but, especially in many developing countries, is seldom capable of doing.

The initiative for creating clusters and networks from below through purposive action emerges from local processes. It is rarely the product of national government interventions, precisely because of the need to be sectorally embedded and establish institutional intimacy with local firms, facilitators and supporting organisations. Hence it is better to have government institutions involved in creating or maintaining clusters that operate at a lower level than the national structures. Whether this should be provincial or local government depends on the resource capabilities and human capacity levels of the different tiers. Central government's tendency to concentrate resources and set up bureaucratically obstructive accessing mechanisms has a major debilitating impact on the ability of firms to gain from networking arrangements. Distant and unresponsive centralised bureaucratic structures do little to enhance the building of relations essential to the uptake of programmes deemed national priorities. Space barriers, distance and limited contact between firms and central government officials do not enhance trust and mutual learning that are essential ingredients for successful networking and clustering.

A major problem obstructing building clusters from below is national government misunderstanding the various stages of creating effective industrial policy and strategy - i.e. formulation, design, promotion and implementation. Policy formulation is usually undertaken by externally based consultants in cooperation with central government producing a coherent set of principles and guidelines which are adopted with suitable modification by government. Policy design translates this into a legal framework as the codified policy of the government undertaken by central bureaucrats and legislative experts. Policy promotion disseminates this to interested stakeholders. Policy implementation ensures that the bureaucratic processes and internal institutional arrangements are in place to deliver on the policy objectives. This requires government departments to reorganise internal institutional arrangements, train staff, change civil servant mind sets, speed up processes etc. to ensure that the policies are accessed, the activities delivered to the relevant parties in the correct time frames, and the results monitored and evaluated. Unfortunately, most policy processes stop at policy promotion, government bureaucrats assuming that dissemination equals implementation, and the crucial issue of ensuring that the necessary institutional arrangements have been put in place to implement the objectives is ignored. In respect of clustering, institutional intimacy and 
embeddedness suggest that these institutional arrangements and interventionist foci are best located within specialised government agencies/departments at lower government levels. A spin off is that the increased local interaction results in major learning by local officials, building knowledge and capacity within the regional system of innovation.

Finding the appropriate level of government to situate public policy initiatives is complicated by the imperatives of globalisation and the impact of global value chains on firms. In previous work we have analysed the automotive sector using the analytic distinction between three kinds of industrial policy (macro, cross-sectoral, and sector specific) and stressed the need for systemic policy integration (Barnes et al 2004, Lall \& Teubal 1998). We have built on this by developing the following matrix (Fig 2) where each cell contains a number of possible initiatives and activities. These are merely illustrative.

Figure 2: Example of an industrial policy and cluster strategy levers framework

\begin{tabular}{|c|c|c|c|c|}
\hline & $\begin{array}{llllll}C & O & M & P & E & T \\
\end{array}$ & $\begin{array}{llllll}\mathbf{T} & \mathbf{I} & \mathbf{V} & \mathbf{E} & \mathbf{N} & \mathbf{E} \\
\end{array}$ & LEV E L S \\
\hline & & Micro level (Intra-firm) & Meso Level (Value Chain/Cluster) & Macro (National) \\
\hline \multirow{2}{*}{$\begin{array}{l}\mathbf{G} \\
\mathbf{O} \\
\mathbf{V} \\
\mathbf{E} \\
\mathbf{R} \\
\mathbf{N} \\
\mathrm{A} \\
\mathbf{N} \\
\mathrm{C} \\
\mathrm{E}\end{array}$} & Global & \multicolumn{3}{|c|}{$\begin{array}{l}\text { WTO, MFA, AGOA, EU Agreement, Internationally agreed certification standards (ISO, labour, fair } \\
\text { trade, eco-labelling), Value chain technical operating performance protocols }\end{array}$} \\
\hline & $\begin{array}{l}\mathrm{C} \\
\mathrm{e} \\
\mathrm{n} \\
\mathrm{t} \\
\mathrm{r} \\
\mathrm{a} \\
\mathrm{l}\end{array}$ & $\begin{array}{l}\text { *Horizontal support policy } \\
\text { (e.g. Competitiveness Fund) } \\
\text { *R\&D/Innovation support } \\
\text { * Resource allocation }\end{array}$ & $\begin{array}{l}\text { *Sectoral stakeholder alignment } \\
\text { *Supply side policy } \\
\text { *R\&D/Innovation support } \\
\text { *Information for VCs/clusters/sectors } \\
\text { *Selective sector assistance levers } \\
\text { *Cross-sectoral resource allocation }\end{array}$ & $\begin{array}{l}\text { *Enabling Framework } \\
\text { *Selective sectoral policy } \\
\text { *Cross-sectoral policy } \\
\text { *Review of industrial policies } \\
\text { *Data Collection } \\
\text { *Policy performance review } \\
\text { *Analyse global sectoral trends }\end{array}$ \\
\hline $\begin{array}{l}\text { P } \\
\text { O } \\
\text { L } \\
\text { I } \\
\text { C } \\
\text { Y }\end{array}$ & $\begin{array}{l}\mathbf{P} \\
\mathrm{r} \\
\mathrm{o} \\
\mathrm{v} \\
\mathrm{i} \\
\mathrm{n} \\
\mathrm{c} \\
\mathrm{e}\end{array}$ & $\begin{array}{l}\text { *Export information } \\
\text { * Firm upgrading support } \\
\text { * Service provider directory } \\
\text { *Information hub } \\
\text { *Build BDS sector }\end{array}$ & $\begin{array}{l}\text { *Market info on global buyers } \\
\text { *Sector trade intelligence } \\
\text { *Information hub to assist supply } \\
\text { chain operational performance } \\
\text { *Cluster/learning network support } \\
\text { *Conduit for horizontal support } \\
\text { measures e.g. funding, monitoring }\end{array}$ & $\begin{array}{l}\text { *Lobbying } \\
\text { *Institutional participation in } \\
\text { national sector councils } \\
\text { *Conduct socio-economic } \\
\text { impact studies }\end{array}$ \\
\hline $\begin{array}{l}E \\
\text { V } \\
\text { E } \\
\text { R } \\
\text { S }\end{array}$ & $\begin{array}{l}\text { L } \\
\text { o } \\
\text { C } \\
\text { a } \\
\text { I }\end{array}$ & $\begin{array}{l}\text { *Optimise infrastructure } \\
\text { *Logistics costs/assistance } \\
\text { *Data collection/analysis } \\
\text { *Skills development }\end{array}$ & $\begin{array}{l}\text { *Cluster/learning network support } \\
\text { *Conduit for horizontal support } \\
\text { measures e.g. funding, monitoring } \\
\text { *Disseminate sector information } \\
\text { * Alignment to province strategies }\end{array}$ & $\begin{array}{l}\text { *Lobby provincial government } \\
\text { * Institutional participation in } \\
\text { sectoral councils) }\end{array}$ \\
\hline
\end{tabular}

In conclusion the issue government and market in creating clusters and learning networks is particularly complicated and fraught because the terms of discussion are wrongly set. There cannot be a cluster without it being situated within a market environment, and it is highly unlikely that we can get sustainable clustering without purposive action. From the perspective of the firms involved, clusters arise because of both institutional and market failure. It is therefore a question of recognising that it is an issue of finding the appropriate balance. Fundamentally the role of government in regional development is to create an enabling environment for firms to engage in collective efficiency to upgrade systemic competitiveness on a long term basis. In all the South African case studies of clusters the underlying rationale and logic of the cluster and the accompanying purposive action is always driven by systemic upgrading, and the role of government is not to help firms simply cut their immediate operating costs - that is a short term agenda and doesn't necessarily contribute to upgrading 
systemic efficiency. The South African clusters cited are driven by policy purposiveness, international competitiveness drivers and an upgrading imperative, and bolstered by the systemic linkages between macro, cross-sectoral and sector specific industrial policy (albeit somewhat erratically implemented). This may be the fundamental difference between spontaneous clustering and purposive clustering in the context of regional development. It is also why we believe that government has a critical role (always taking into account capacity limitations) to play in fostering purposive clusters - not because of support for a particular set of firms, but because of the congruence between the broader developmental objectives of national and/or regional government and the firm-level upgrading challenges confronting individual firms and clusters of firms in particular localities.

\section{REFERENCES}

Altenburg, Tilman and Jorg Meyer-Stamer (1999). "How to Promote Clusters: Policy Experiences from Latin America.” World Development 27(9)

Barnes J, Kaplinsky R, \& Morris M, (2004) “Industrial Policy in Developing Economies: Developing Dynamic Comparative Advantage in the South African Automobile Sector”, Competition and Change, 8, 2.

Barnes J \& Morris M, (1999), "Improving Operational Competitiveness Through Firm Level Clustering: A Case Study of the KwaZulu-Natal Benchmarking Club”, Working Paper 24, School of Development Studies, University of Natal

Barnes J \& Lorentzen J, (2004), 'Learning, upgrading and innovation in the South African automotive industry’, European Journal of Development Research, 16, 3, Autumn,

Bessant J, Kaplinsky R \& Morris M, (2003), “Developing Capability Through Learning Networks”, in International Journal of Technology Management and Sustainable Development, 2 (1)

Bell M and Albu M, (1999), "Knowledge Systems and Technological Dynamism in Industrial Clusters in Developing Countries”, in World Development, 27 (9)

Chang, H-Joon (1994), The Political Economy of Industrial Policy, New York: St Martin’s Press.

Chang, H-Joon (1998), Evaluating the Current Industrial Policy of South Africa, Transformation, 36.

Chang, H-Joon (2002), Kicking Away the Ladder: Development Strategy in Historical Perspective, Wimbledon: Anthem Press.

Dicken P (1998) Global Shift: Transforming the World Economy, Paul Chapman, London.

Enright M and Ffowcs-Williams, I (2000), 'Local Partnership, Clusters and SME Globalisation', Organisation for Economic Co-operation and Development, www.oecd.org/dataoecd/20/5/2010888.pdf

Gereffi G, Humphrey J \& Sturgeon T (2004), 'The governance of global value chains', Review of International Political EconomyI, 12, 1

Helmsing A H J, (2001), “Externalities, Learning and Governance: New Perspectives on Local Economic Development”, Development and Change, 32 (2)

Humphrey, J and H Schmitz (1995). "Principles for promoting clusters \& networks of SMEs.” Vienna: UNIDO. www.unido.org.

Humphrey J and Schmitz H, (1996), “The Triple C Approach to Local Industrial Policy”, World Development, 2412

Humphrey J and Schmitz H, (2002), "How does insertion in global value chains affect upgrading in industrial clusters” Regional Studies, 36, 9

Kaplinsky R, (2005) Globalization, Poverty and Inequality: Between a rock and a hard place, Polity Press, London.

Kaplinsky R \& Morris M, (2001), A Handbook for Value Chain Research, www.ids.ac.uk/ids/global

Lall, S (2004) "Reinventing industrial strategy: the role of government policy in building industrial competitiveness”, TIPS working paper, 9.

Lall, S. \& Teubal, M. (1998) Market stimulating technology policies in developing countries: a framework with examples from East Asia, World Development, 26,

Lawson C and Lorenz E, (1999), “Collective Learning, Tacit Knowledge and Regional Innovative Capacity”, in Regional Studies, 33 (4)

Maskell P, Eskelinen H, Hannibaldson I \& Malmberg A \& Vatne E, (1998), Competitiveness. Localized Learning and Regional Development: Specialization and Prosperity in Small Open Economies, Routledge, London

Morosini P, (2004), “Industrial Clusters, Knowledge Integration and Performance”, World Development, 32 (2)

Morris M \& Barnes J, (2004), "Policy Lessons in Organising Cooperation and Facilitating Networked Learning in Value Chains and Industrial Clusters”, www.ukzn.ac.za/csds 
Morris, Barnes and Esselaar 2006 (2006). "Globalisation, the changed global dynamics of the clothing and textile value chains and the impact on sub-Saharan Africa.” in Memedovic (ed), Global Value Chains and Production Networks: Prospects for Upgrading by Developing Countries. Vienna: UNIDO.

Nadvi K, (1999), "Shifting Ties: Social Networks in the Surgical Instrument Cluster of Sialkot, Pakistan”, in Development and Change, 30

Nadvi K \& Schmitz H, (1999), “Clustering and Industrialisation”, in World Development, 27 (9)

Peck F \& McGuinness, D (2003), "Regional Development Agencies and Cluster Strategies: Engaging the Knowledge-base in the North of England", in Local Economy, 18 (1), p 46-62

Schmitz H, (1999a), “Collective Efficiency and Increasing Returns”, Cambridge Journal of Economics, 23 (4)

Schmitz H, (1999b), "Global Competition and Local Cooperation: Success and Failure in the Sinos Valley, Brazil”, in World Development, 27 (9)

Schmitz H (2004), (ed) Local Enterprises in the Global Economy: Issues of governance and upgrading, Edward Elgar.

Teece, D., and G. Pisano (1994), “The dynamic capabilities of firms: an introduction”, Industrial and Corporate Change, 3, pp 537-556.

World Bank, (1997), World Development Report: The State in a Changing World, The World Bank, Oxford University Press

World Bank (2004) website on "Program and Project Options: Implementing LED. More Information on

Cluster and/or Sector Development” (www.worldbank.org/urban/led/cluster2.html) 